\title{
Combating COVID-19: Temperature could be a key
}

\author{
Indrani Roy, UK \\ (indrani.roy@ucl.ac.uk) \\ (Publons: Link; Google scholar: Link; ResearchGate: Link)
}




\section{Motivation}

\section{More than 530,000 people died till $4^{\text {th }}$ of July 2020.}

- Economy and mental health suffered tremendously.

- No proven cure for the disease is found yet.

- Popular known methods to treat disease are Plasma therapy, Vaccine development, Medication etc. But those are not yet comprehensively tested. In addition, time consuming and with potential side effects.

- With that Emergency Situation in mind some urgent, simple solutions were proposed on $17^{\text {th }}$ March (Roy, 2020a) purely based on Science.

- These are without side effects, no funding required, no vested interest, can be practiced in own home. 


\section{Outline}

- Background: Scientific Analyses

- Background: Clinical Trials

- Global Air Temperature- Mid Feb to April, 2020

- Vulnerability measured: Death per Million

- Solutions:

> General

> Cold Country Specific

> Economically Weaker Specific 


\section{Background: Scientific Analyses}

This family of viruses is very sensitive to Temperature.

- True for this virus SARS-CoV-2 responsible for COVID19: Scafetta N., (2020); Paulo M et al., (2020); Roy I., (2020).

- Paulo M. et al. (2020) in a review work presented seventeen recent papers on COVID-19 and almost all found strong connections of temperature.

- True for similar generic category Coronavirus SARS and MARS (Van Doremalen N., 2013; Chan et al., 2011).

- True for other similar Seasonal air-borne Flu viruses (Lowen et al., 2007). 


\section{Temperature Sensitivity: Clinical Trials}

- Seasonally dependent endemic virus (Lowen et al., 2007): Temperature of $5{ }^{\circ} \mathrm{C}$ and Relative Humidity $(\mathrm{RH}) 35 \%$ to $50 \%$, infection rate was very high (75-100\%). Whereas, when $\mathrm{RH}$ was still kept at $35 \%$, but only temperature was increased to $30^{\circ} \mathrm{C}$, infection rate surprisingly reduced to zero.

- True for similar Coronavirus genus SARS and MARS: Virus remain active for a long time in low temperature (Van Doremalen N., 2013). Low temperature significantly contributes to the survival and transmission of the virus (Casanova et al., 2010; Chan et al., 2011; Seung et al., 2007).

- Typical Air-Conditioning Temperature: SARS could be active for at least five days in typical airconditioned environments which has relative humidity $40-50 \%$ and room temperature $22-25^{\circ} \mathrm{C}$ (Chan et al., 2011).

- Similar generic Coronavirus (viz. SARS-CoV) using a variable Temperature (Casanova et al., 2010): Inactivation of virus was faster at all humidity level if temperature was simply raised to $20^{\circ} \mathrm{C}$ from $4^{\circ} \mathrm{C}$, more rapid if the temperature was further increased to $40^{\circ} \mathrm{C}$ from $20^{\circ} \mathrm{C}$. 


\section{Transmission of Disease and Temperature}

COVID-19 is extremely contagious and invaded most of the globe in less than two months.

Attention: Understand nature of its transmission under variable temperature condition.

I Lab experiment with Guinea Pigs (Lowen et al., 2007):

Using similar seasonal air-borne virus, it studied effect of temperature on Airborne Transmission as well as Contact Transmission. Increasing temperature prevented airborne transmission but not contact transmission. When guinea pigs were kept in separate cages at temperature of $30^{\circ} \mathrm{C}$ for 1 week, no recipient guinea pigs were infected. But if those were kept in same cage to simulate contact transmission, between $75 \%$ and $100 \%$ became infected. No role of humidity found in these experiments. 


\section{Global Air Temperature:}

\section{Mid-February to April 2020}

NCEP/NCAR Reanalysis

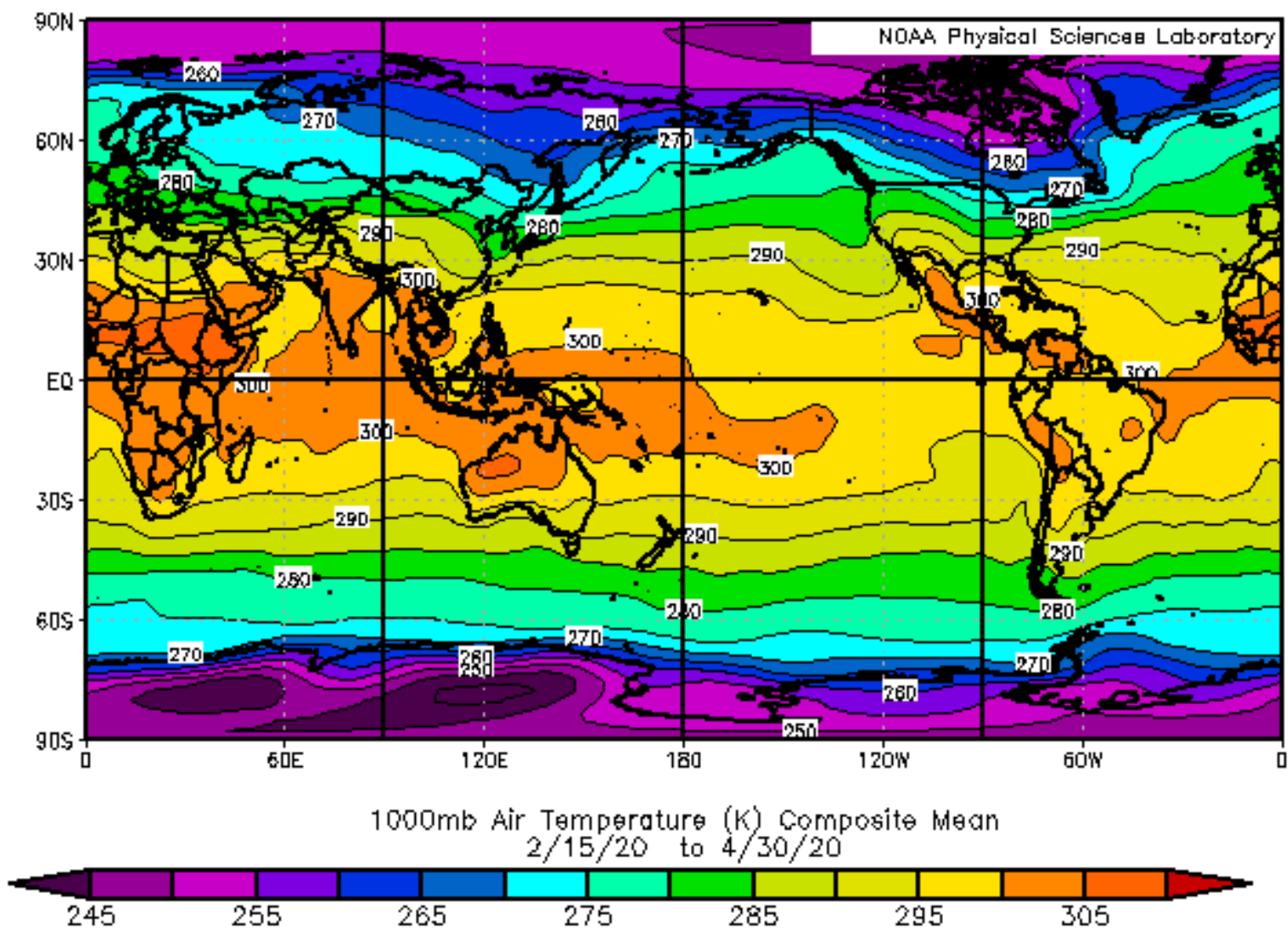

Monthly average air temperature ( $\left({ }^{\circ} \mathrm{K}\right)$ from mid-February to April 2020.

(Plot generated: https://psl.noaa.gov/data/composites/day/ )

[Source: Roy, (2020)] 


\section{Vulnerability measured in: Deaths per Million}

\section{(till 1 ${ }^{\text {st }}$ May)}

Total Death per Million (upto 1st May)

Uncertainty:one Standard Deviation

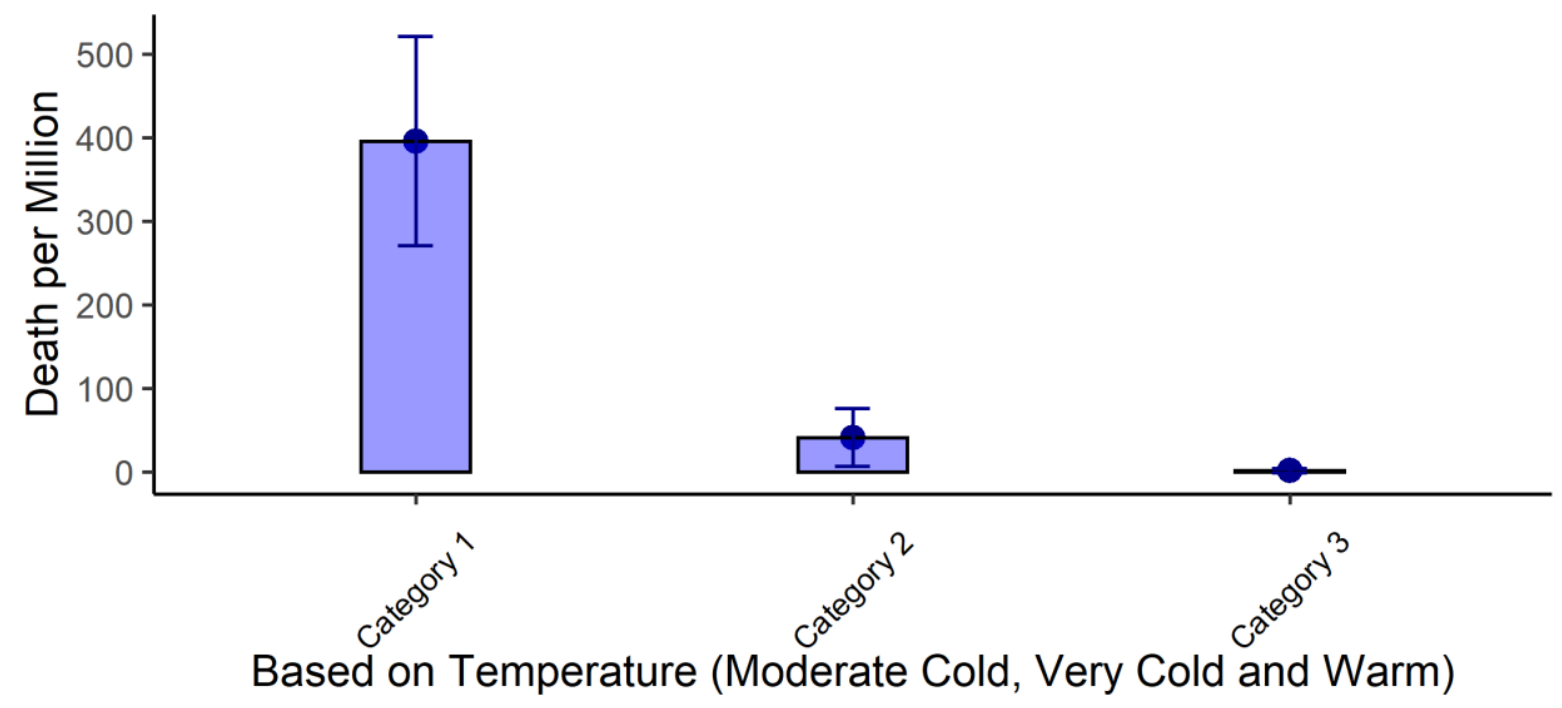

[Source: Roy, (2020)]

Difference among Category 1 (Moderate Cold), Category 2 (Very Cold) and Category 3 (warm) were Statistically Significant.

Moderately Cold: USA, UK, Italy, Spain, France Very Cold: Canada, Russia, Finland, Iceland Warm: SAARC, South East Asian Countries, African Continents, Australia. 


\section{Temperature Sensitivity - Proof for all countries from SAARC and SEAC}

Death in SAARC, South East Asian countries (upto 1st of May)

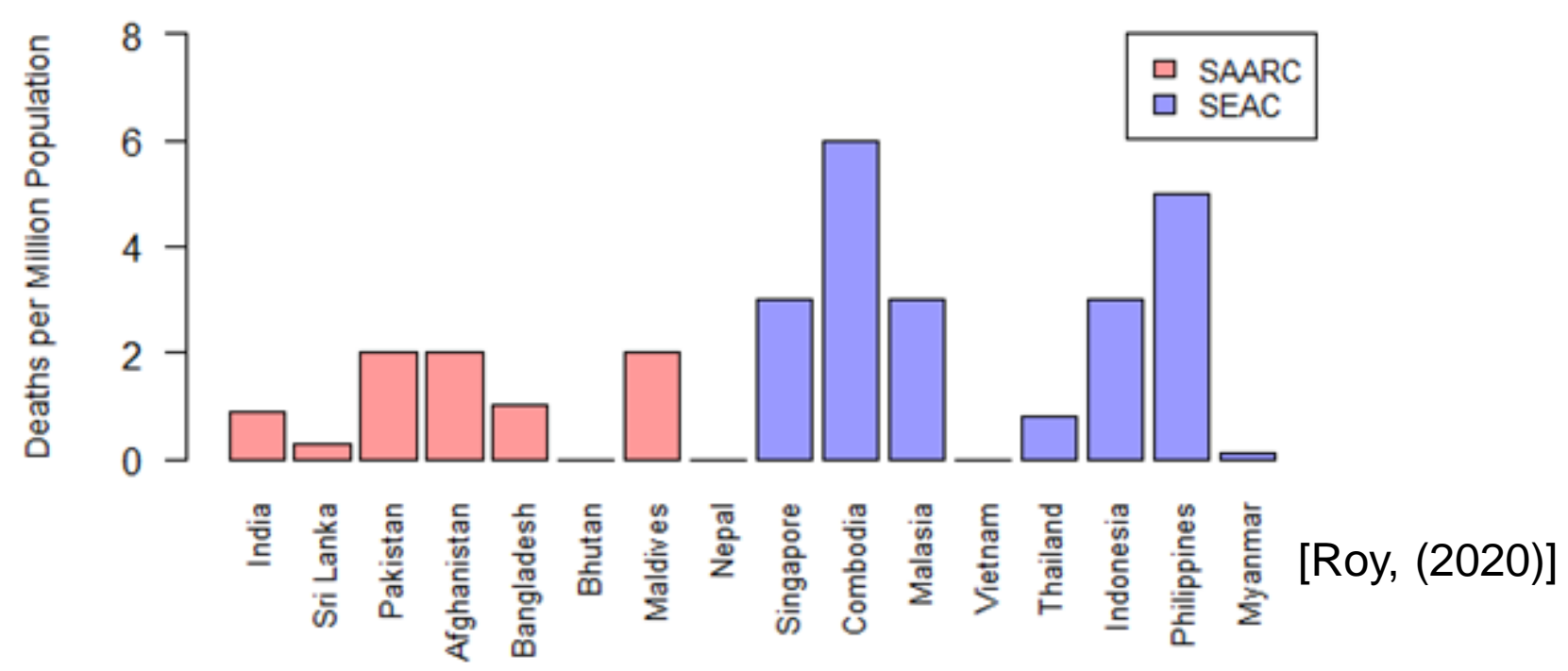

- Varied characteristics: popular tourist spots, international business hubs with more foreign travellers, level of testing, infrastructural facility, population density, different degree of lockdown restrictions.

- In spite of all dissimilarities still one common factor: Death per Million for all those countries from SAARC and SEAC were much less and the pattern is still maintained. It was lesser than 8 till $1^{\text {st }}$ of May, while in Spain it was 531, Italy 467and UK 405.

Because of large population, India is now one of the highest ranked in overall counts of total Deaths, as well as total Cases. 


\section{Temperature sensitivity of the virus SARS-CoV-2 and Global transmission}

\section{Global Temperature analyses: till $1^{\text {st }}$ May Vulnerability measured in: Deaths per Million}

- Moderately cool environment was the most favourable state for susceptibility of virus. Countries like USA, UK, Spain, Italy etc.

- Risks from the virus were reduced significantly in very high temperature environment. Part of African continents, Australia.

- Warm countries and places were likely to be less vulnerable. E.g., SAARC, South East Asian countries, African continents, Australia.

- Countries with very cold temperature were moderately affected in March-April (e.g. Canada, Russia, Scandinavian countries).

- Transition: Countries can switch from one vulnerability state to another based on variability of temperature. E.g. South American countries turned warm to cooler in June, while Canada and Russia from very cold to moderate cold. Death rate increased in those countries. Europe tuned warmer from moderately cold and death rate decreased. 


\section{Solutions: General Measures}

- Using the Sauna facility: Usually hotels, gyms, leisure centres have existing Sauna facilities. Also, mobile and Caravan Sauna facilities can be thought of in future.

- Disinfect any place using high temperature: Before start of office, school or business, temperature of premises may be kept very high, (say, $60^{\circ} \mathrm{C}$ ) for half an hour. For airports, train and bus, same method of disinfecting could be thought of. Optimum temperature and duration can be tested easily. For any external object or material, disinfecting using very high temperature could be a useful solution.

- Using Blow dryers: Inhale hot air through nose few times a day to kill virus in nasal cavity. Blow dryer and hot drinks are useful at initial stages of disease and asymptomatic or pre-symptomatic states.

- Hot Drinks: Hot drinks (could be tea, coffee, hot lemon juice, etc.), gargle with warm salt water few times a day to destroy virus in throat.

Why: Virus is very sensitive to Temperature. It mainly enters through nose (WHO). Testing done with swap from nasal cavity and back of the mouth. 


\section{Solutions: Cold Country Specific}

The virus is very sensitive to Temperature.

- Portable Room Heater: Stay close to a portable room heater with comparatively high temperature say, twice a day and preferably for half an hour. Being portable in nature, it can be moved around and many people can avail that facility in a flexible way. Room heaters can also be useful for disinfecting purposes.

- Regulate room temperature of air conditioning: Maintain room temperature a bit higher than usual. Maintaining comfort level, a high temperature threshold can be regulated inside offices, schools, colleges, shopping malls etc. Attention should be more on sensitive places like old care homes, health centres, and hospitals (other than special treatment units where cold temperature is essential or recommended).

All solutions are supported by Science and can further

be strengthened by clinical trials, side by side. 


\section{Solutions: Options for Lower income groups, Rural and Remote locations}

The virus is very sensitive to Temperature.

- Green House (glass): It would be useful in poor countries and rural places without electricity. During the day, bright sunshine can provide heat by Green House effect.

- Outside Raw Fire: In underdeveloped countries and rural places, people usually circle round in a camp-fire style fire in winter. They use dry leaves and spare woods for a small fire. That heat in winter could be useful.

- Substitute of Blow Dryer and Room Heater: While cooking, all members of the household could be, in turn, stay close to the heat source, for, say, half an hour a day. Also, each individual can use separate folded cotton cloths to take heat from the cooking container and use on the nose. 


\section{Caution and Additional Points}

Caution: If people already developed major symptoms, then all these methods discussed will not be effective and proper medical advice need to be solicited.

\section{Additional Points:}

- Water shortage: Whether frequent Hand Washing can be replaced by sensor-based hand dryer (normally found in a washroom).

- Plastic Disposal: Personal Protective Equipment (PPE) are single use. World is already under stress due to problems of disposing Plastic. If PPE can be disinfected using heat-based solutions and reused. It can be tested in laboratory and could prove very beneficial.

- Face Shield /Visors: In busy public places, mass gathering, and cold premise, face shield will give additional protection. The virus can also enter through eyes (ECDC).

- Contact Transmission: For warm, highly populated countries, contact transmission could play important role and appropriate measures can be taken. E.g., A/C premises, where mass gathering happens need disinfecting on a regular basis. 


\section{The virus in very sensitive to Temperature}

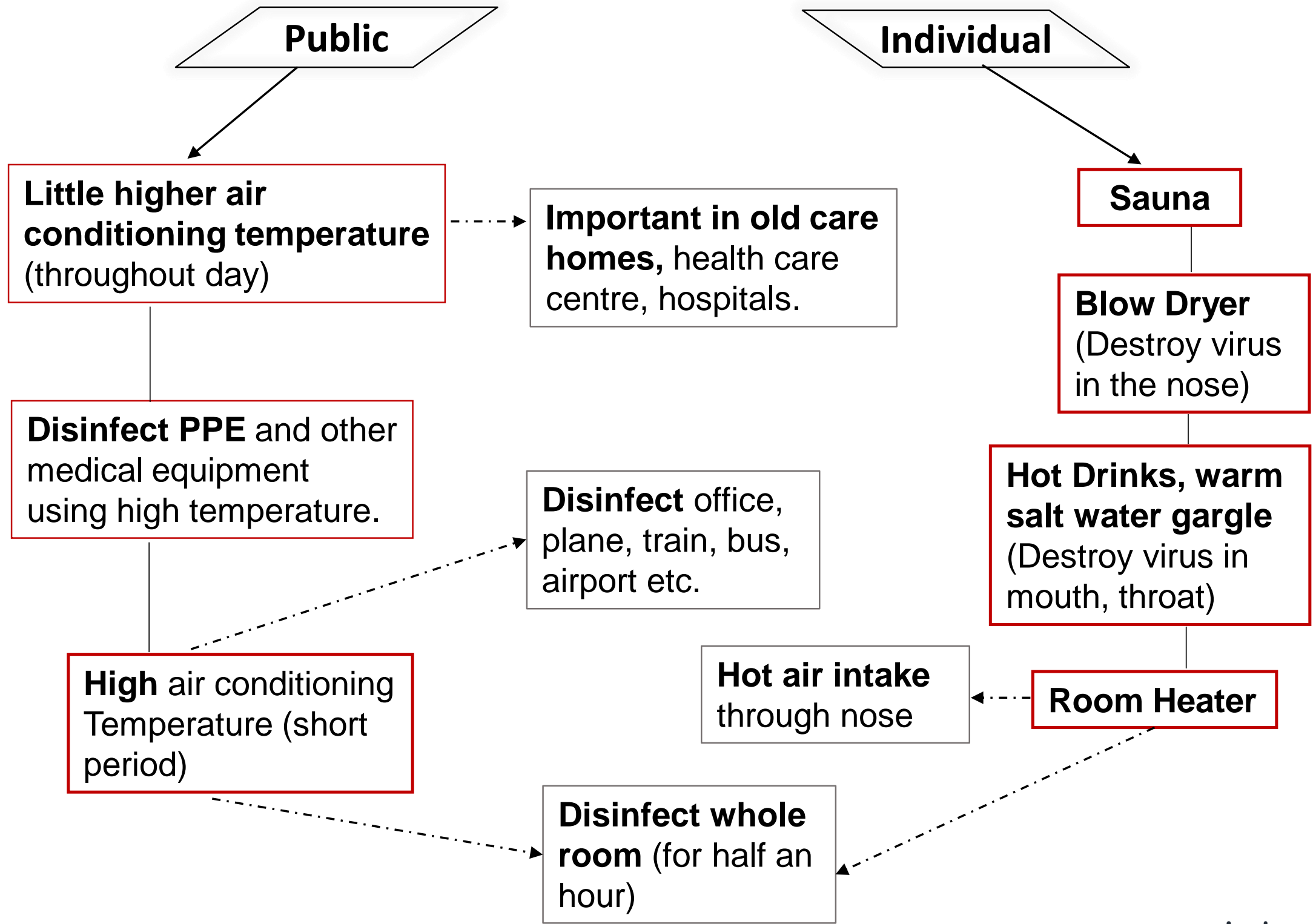

\begin{tabular}{|c|c|c|}
\hline $\begin{array}{l}\text { Little higher air } \\
\text { conditioning temperature } \\
\text { (throughout day) }\end{array}$ & -.. & $\begin{array}{l}\text { Important in old care } \\
\text { homes, health care } \\
\text { centre, hospitals. }\end{array}$ \\
\hline
\end{tabular}

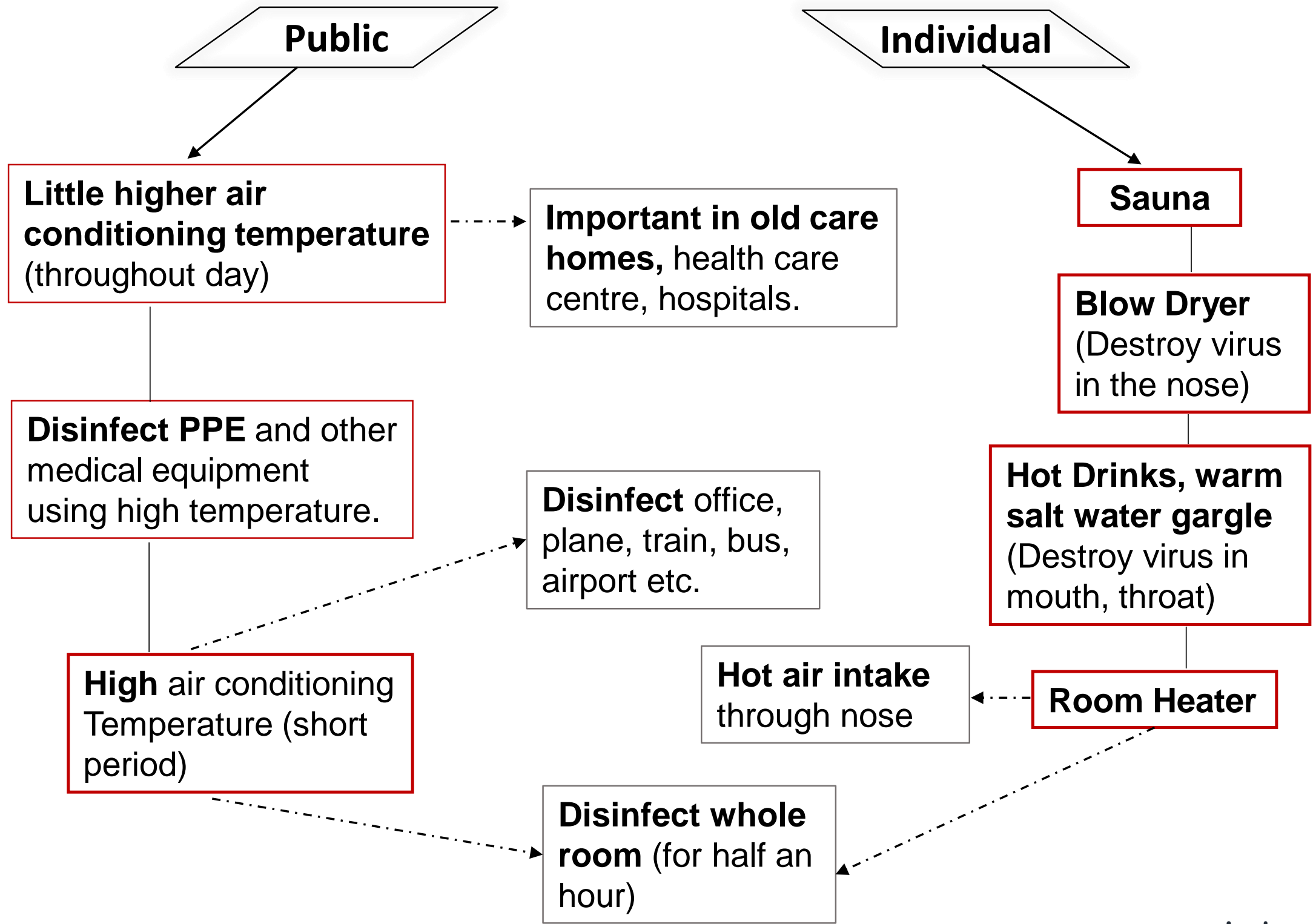




\section{References}

- Casanova L. et al., (2010): Effects of Air Temperature and Relative Humidity on Coronavirus Survival on Surfaces, Appl Environ Microbiol. 76(9): 2712-2717. doi: 10.1128/AEM.02291-09.

- Lowen A. C. et al., (2007). Influenza virus transmission is dependent on relative humidity and temperature. Pathogens 3, pp. 1470-1476.

- Paulo M. et al. (2020), Effects of temperature and humidity on the spread of COVID19: a systematic review, preprint, https://doi.org/10.1101/2020.04.14.20064923

- Roy I., (2020), Influence of Temperature on the Global Spread of COVID-19, preprint, doi: 10.20944/preprints202003.0366.v3

- Scafetta N., (2020), Distribution of the SARS-CoV-2 pandemic and its monthly forecast based on seasonal climate patterns. Int. J. Environ. Res. Public Health, 17(10), 3493. https://doi.org/10.3390/ijerph17103493

- Seung W. K. et al., (2007). Effects of humidity and other factors on the generation and sampling of a coronavirus aerosol. Aerobiologia. $23.239-248$. https://doi.org/10.1007/s10453-007-9068-9

- Van Doremalen N. et al., (2013). Stability of Middle East respiratory syndrome coronavirus (MERS-CoV) under different environmental conditions. Euro Surveill,18(38), https://doi.org/10.2807/1560-7917.ES2013.18.38.20590 


\section{Interested in Details}

- Roy, I. (2020a), Combating recent pandemic of

COVID-19 - An urgent Solution. dt 17 th March 2020,

(doi: 10.13140/RG.2.2.22632.83208);

- Roy, I. (2020b), Atmospheric Variables and Additional Urgent Solutions for Combating COVID-19 dt $9^{\text {th }}$ April. (doi: 10.20944/preprints202003.0366.v2)

- Roy, I. (2020c) Influence of Temperature on the Global Spread of COVID-19. Preprints, dt $21^{\text {st }}$ June (doi: 10.20944/preprints202003.0366.v3) 
Thank Oyou 